\title{
PENGARUH KOMPOSISI MEDIA TANAM DAN KONSENTRASI PAKLOBUTRAZOL TERHADAP KERAGAAN TANAMAN CABAI (Capsicum annuum L.) CV “Candlelight” PADA BUDIDAYA TANAMAN SECARA HIDROPONIK
}

\author{
Arpin Bahreka Putra, Tri Dewi Andalasari, Yohannes Cahya Ginting \& Rugayah \\ Jurusan Agroteknologi Fakultas Pertanian Universitas Lampung. \\ J1. Sumantri Brojonegoro No.1 Bandar Lampung 35145
}

\begin{abstract}
ABSTRAK
Capsicum annuum L. CV. "Candlelight" atau sering disebut cabai rawit tumpuk memiliki buah beraturan seperti kumpulan lilin yang menyala, cocok untuk ditanam di pot. Tanaman cabai Candlelight memiliki potensi menjadi tanaman hias, dengan membuat tinggi tanaman lebih pendek, daun lebih hijau, cabang dan jumlah daun lebih banyak melalui pemberian paklobutrazol dan penggunaan media tanam yang tepat melalui budidaya tanaman secara hidroponik. Penelitian ini bertujuan untuk mengetahui pengaruh komposisi media tanam, konsentrasi paklobutrazol dan interaksi keduanya terhadap keragaan tanaman cabai Candlelight pada budidaya tanaman secara hidroponik. Penelitian dilaksanakan pada bulan Desember 2015 sampai Juni 2016 di Rumah Kaca Universitas Lampug dengan Rancangan Acak Kelompok. Perlakuan disusun faktorial 2 x 5 dengan 3 kelompok yang terdapat 2 sub sampel. Faktor pertama adalah komposisi media tanam $(\mathrm{M})$ terdiri dari; sekam bakar $\left(\mathrm{m}_{1}\right)$, dan sekam bakar + sekam mentah 1:1 ( $\left.\mathrm{m}_{2}\right)$. Faktor kedua konsentrasi paklobutrazol (D) terdiri; dari $0 \mathrm{ppm}\left(\mathrm{d}_{0}\right), 25 \mathrm{ppm}\left(\mathrm{d}_{1}\right), 50 \mathrm{ppm}$ $\left(\mathrm{d}_{2}\right), 75 \mathrm{ppm}\left(\mathrm{d}_{3}\right)$, dan $100 \mathrm{ppm}\left(\mathrm{d}_{4}\right)$. Homogenitas ragamn diuji dengan Uji Bartlett dan aditivitas dengan Uji Tukey. Pemisahan nilai tengah diuji dengan Uji Polinomial Ortogonal pada taraf 5\%. Hasil penelitian menunjukan media sekam bakar hasil lebih baik dibandingkan sekam campuran. Konsentrasi paklobutrazol $50 \mathrm{ppm}$ berpengaruh terhadap jumlah daun total, tinggi tanaman, jumlah tunas, muncul bunga pertama, jumlah bunga, jumlah cabang, jumlah buah, umur buah di tanaman, panjang buah, dan kehijauan daun. Jumlah buah pada media sekam bakar tidak ada pengaruh paklobutrazol tetapi pada media campuran pengaruh konsentrasi paklobutrazol memberikan pengaruh. Pada media sekam bakar setiap penambahan konsentrasi 1 ppm paklobutrazol menurunkan tinggi tanaman sebesar $0,2 \mathrm{~cm}$, sedangkan pada media sekam campuran paklobutrazol menurunkan tinggi tanaman sebesar $0,36 \mathrm{~cm}$.
\end{abstract}

Kata kunci : cabai candlelight, hidroponik, media tanam, paklobutrazol

\section{PENDAHULUAN}

Umumnya untuk cabai hias pot keragaan yang diinginkan adalah tanaman yang mempunyai pertumbuhan yang normal, proporsional dengan pot jika ditempatkan di atas meja sekalipun, daun yang rimbun, berbunga kompak, mempunyai jumlah buah yang banyak serta warna daun yang hijau (Gambar 1). Salah satunya dengan penggunaan media tanam yang tepat serta zat penghambat tumbuh pada tanaman yang dapat mempengaruhi sifat fisiologis tanaman tersebut.

Prayugo (2007) dalam Riyanti (2009) menyebutkan bahwa media tanam yang baik harus memiliki kemampuan mengikat air dan menyuplai unsur hara yang dibutuhkan tanaman, mampu mengontrol kelebihan air (drainase) serta memiliki sirkulasi dan ketersediaan udara (aerasi) yang baik, dapat mempertahankan kelembaban di sekitar akar tanaman dan tidak mudah lapuk atau rapuh. Jenis bahan organik yang dapat dijadikan sebagai media tanam diantaranya sekam padi dan sekam bakar. Sekam padi mengandung beberapa unsur kimia penting seperti C 1,33\%, H 1,54\%, O $33,64 \%$, S 16,98\%, kadar air 9,02\%, serat kasar $35,68 \%$, dan abu 17,17\% Riyanti (2009). Arang sekam mengandung $\mathrm{SiO}_{2}(52 \%), \mathrm{C}(31 \%), \mathrm{K}(0.3 \%), \mathrm{N}$ $(0,18 \%), \mathrm{F}(0,08 \%)$, dan $\mathrm{Ca}(0,14 \%)$. Selain itu juga mengandung unsur lain seperti $\mathrm{Fe}_{2} \mathrm{O}_{3}, \mathrm{~K}_{2} \mathrm{O}, \mathrm{MgO}, \mathrm{CaO}$, $\mathrm{MnO}$ dan $\mathrm{Cu}$ dalam jumlah yang kecil (Marlina dan Rusnandi, 2007).

Selain penggunaan media tanam yang tepat penggunaan zat pengatur tumbuh berperan dalam mempengaruhi tanaman. Paklobutrazol merupakan salah satu zat pengatur tumbuh yang berfungsi untuk menghambat biosintesis giberelin sehingga dapat menurunkan pertumbuhan vegetatif dan memacu pertumbuhan generatif. Paklobutrazol adalah zat pengatur tumbuh yang daya kerjanya menghambat biosintesis giberelin sehingga dapat menurunkan 
pertumbuhan vegetatif dan memacu pertumbuhan generatif(Wattimena, 1988).

Penggunaan cara budidaya yang tepat juga mempengaruhi hasil dari cabai hias tersebut, selain perhitungan biaya produksi juga perhitungan permintaan konsumen yang semakin meningkat baik kualitas dan kuantitasnya, oleh karena itu digunakan metode budidaya secara hidroponik yang menghasilkan kuantitas dan kualitas produksi lebih tinggi dan lebih bersih, serta penggunaan pupuk dan air lebih efisien sehingga mendapatkan hasil lebih maksimal.

Berdasarkan uraian tersebut untuk menciptakan keragaan yang sesuai maka penambahan zat pengatur tumbuh seperti paklobutrazol dengan konsentrasi 0, 25, 50, 75, dan 100 ppm (Gambar 2). Penggunaan paklobutrazol untuk menciptakan tanaman yang berkeragaan tidak terlalu tinggi, berbunga kompak, dan mempunyai jumlah buah yang banyak karena dengan penambahan paklobutrazol akan terjadi penghambatan produksi giberelin pada tanaman sehingga tanaman akan lebih berbunga. Pada penelitian ini dilakukan pengujian untuk melihat pengaruh komposisi media tanam dan konsentrasi paklobutrazol terhadap tanaman cabai CV. Candlelight. Hal ini dimaksudkan untuk mendapatkan keragaan tanaman yang kompak sebagai tanaman hias pot.

\section{BAHAN DAN METODE}

Penelitian ini dilaksanakan dari bulan Desember 2015 sampai dengan Juni 2016. Penanaman dilakukan di Rumah Kaca Fakultas Pertanian Universitas Lampung. Alat yang digunakan pada penelitian ini adalah; polibag, hand sprayer, alat ukur, ember, gelas plastik, gelas ukur, mika bolu ukuran $25 \times 25 \mathrm{~cm}$, spuit (suntikan ukur), kamera digital, SPAD (klorofil meter), hand sprayer dan alat tulis. Bahan - bahan yang digunakan pada penelitian ini adalah benih cabai "Canddlelight", Furadan berbahan aktif karbofuran $3 \%$, fungisida berbahan aktif propineb $70 \%$, Bakterisida berbahan aktif streptomisinsulfat $20 \%$, paklobutrazol 250 $\mathrm{g} / \mathrm{l}$, Insektisida berbahan aktif profenofos $500 \mathrm{~g} / 1$, larutan pupuk diramu dengan standar (Tonny dan Prabaningrum,2011) (Tabel 1) air, sekam dan, sekam bakar .

Penelitian ini menggunakan Rancangan Acak Kelompok (RAK). Perlakuan disusun faktorial 2 x 5 dengan 3 kelompok yang setiap kelompok terdapat 2 sub sampel. Pengelompokan dilakukan berdasarkan tinggi tanaman 7,2 - 13,8 cm, 5,9 - 7,2 cm, dan 4,1 - 5,9 $\mathrm{cm}$. Faktor pertama adalah komposisi media tanam (M) yang terdiri dari; sekam bakar $\left(\mathrm{m}_{1}\right)$, dan sekam bakar + sekam mentah 1:1 $\left(\mathrm{m}_{2}\right)$. Faktor kedua yaitu konsentrasi paklobutrazol (D) yang terdiri; dari $0 \mathrm{ppm}\left(\mathrm{d}_{0}\right), 25 \mathrm{ppm}$ $\left(\mathrm{d}_{1}\right), 50 \mathrm{ppm}\left(\mathrm{d}_{2}\right), 75 \mathrm{ppm}\left(\mathrm{d}_{3}\right)$ dan $100 \mathrm{ppm}\left(\mathrm{d}_{4}\right)$. Homogenitas ragamnya diuji dengan Uji Bartlett dan aditivitas dengan Uji Tukey. Pemisahan nilai tengah diuji dengan Uji Polinomial Ortogonal pada taraf 5\%.

Penelitian ini dilaksanakan melalui beberapa tahapan, yaitu persiapan media tanam. Pembuatan larutan stok yang diramu dengan standar (Tonny dan Prabaningrum, 2011) (Tabel. 1). Penanaman dilakukan dengan cara membuat lubang tanam sedalam $2-3 \mathrm{~cm}$. Pemeliharaan tanaman meliputi penyiraman, penyulaman tanaman, pengendalian hama dan penyakit, pemupukan, dan memberi patok untuk tanaman yang rebah. Penyiraman dilakukan dua kali dalam seminggu bersamaan dengan pemupukan sebanyak $250 \mathrm{ml}$ per tanaman. Aplikasi paklobutrazol dilakukan satu kali setelah tanaman berumur 1 bulan setelah tanam.

Pemanenan dilakukan dengan dua cara. Pertama pemanenan ditentukan berdasar-kan penampilan luar tanaman. Ciri - ciri tanaman yang sudah siap panen adalah buah mulai menguning. Sehingga tanaman siap untuk ditampilkan. Kedua untuk mengukur bobot buah dan stok benih pemanenan dilakukan saat buah secara kese-luruhan buah sudah berwarna merah.

Variabel yang diamati jumlah daun total, tinggi tanaman, jumlah tunas, muncul bunga pertama, jumlah bunga, jumlah cabang, jumlah buah, panjang cabang, umur buah di pohon, panjang buah, bobot buah, dan kehijauan daun.

\section{HASIL DAN PEMBAHASAN}

Hasil penelitian ini menunjukkan bahwa media sekam bakar memberikan hasil lebih baik dibandingkan media campuran (sekam bakar 50\% + sekam mentah 50\%) (Tabel 1). Menurut Siswadi dan Yuwono (2015) media tanam sekam bakar merupakan media tanam hiroponik yang terbaik memberikan pertumbuhan dan hasil tanaman selada (Lactuca sativa L) dibanding dengan media tanam pasir, sekam padi dan arang. Media sekam bakar dikenal sebagai campuran media yang cukup baik untuk mengalirkan air, sehingga media tetap terjaga kelembabannya. Selain itu arang sekam juga memiliki kemampuan untuk menjernihkan air dan juga menghalang penyakit (Prihmantoro dan Indriani, 2003).

Pada variabel jumlah daun dan panjang buah berbeda nyata pada setiap pemberian konsentrasi paklobutrazol (Tabel 2). Berdasarkan penelitian Yasin (2009) jumlah daun berpengaruh terhadap peZ. Aplikasi paklobutrazol pada konsentrasi $\mathrm{d}_{0}(0 \mathrm{ppm})$ dan $\mathrm{d}_{1}(25$ ppm) tidak berbeda nyata pada variabel jumlah tunas, 
Tabel 1. Formulasi unsur hara untuk larutan stok

\begin{tabular}{lcc}
\hline \multicolumn{1}{c}{ Nama kimia } & Rumus Kimia & $(\mathrm{Kg} / 90 \mathrm{~L}$ air $)$ \\
\hline A & & \\
Kalsium ammonia nitrat & $\left.5 \mathrm{Ca}\left(\mathrm{NO}_{3}\right)_{2} \cdot 2 \mathrm{H}_{2} \mathrm{O}\right)$ & 15,41 \\
Kalium nitrat & $\mathrm{KNO}_{3}$ & 7,038 \\
Fe-EDTA & $\mathrm{Fe}-\mathrm{EDTA}$ & 0.075 \\
& & \\
B & & \\
Kalium hidrofosfat & $\mathrm{KH}_{2} \mathrm{PO}_{4}$ & 8,056 \\
Kalium nitrat & $\mathrm{KNO}_{3}$ & 3,384 \\
Ammonium sulfat & $\left(\mathrm{NH}_{4}\right)_{2} \mathrm{~S}_{4}$ & 0,547 \\
Kalium sulfat & $\mathrm{K}_{2} \mathrm{SO}_{4}$ & 2,827 \\
Magnesium sulfat & $\mathrm{MgSO}_{4} \cdot 7 \mathrm{H}_{2} \mathrm{O}$ & 14,202 \\
Mangan sulfat & $\mathrm{MnSO}_{4} \cdot 4 \mathrm{H}_{2} \mathrm{O}$ & 0,1440 \\
Tembaga sulfat & $\mathrm{CuSO}_{4} \cdot 5 \mathrm{H}_{2} 0$ & 0,0072 \\
Seng sulfat & $\mathrm{ZnSO}_{4} \cdot 7 \mathrm{H}_{2} \mathrm{O}$ & 0,0235 \\
Asam borat & $\mathrm{H}_{3} \mathrm{BO}_{3}$ & 0,119 \\
Natrium hepta molibat & $\left(\mathrm{NH}_{4}\right)_{6 \mathrm{Mo}_{7} \mathrm{O}_{24} \cdot 4 \mathrm{H}_{2} 0}$ & 0,002 \\
\hline
\end{tabular}

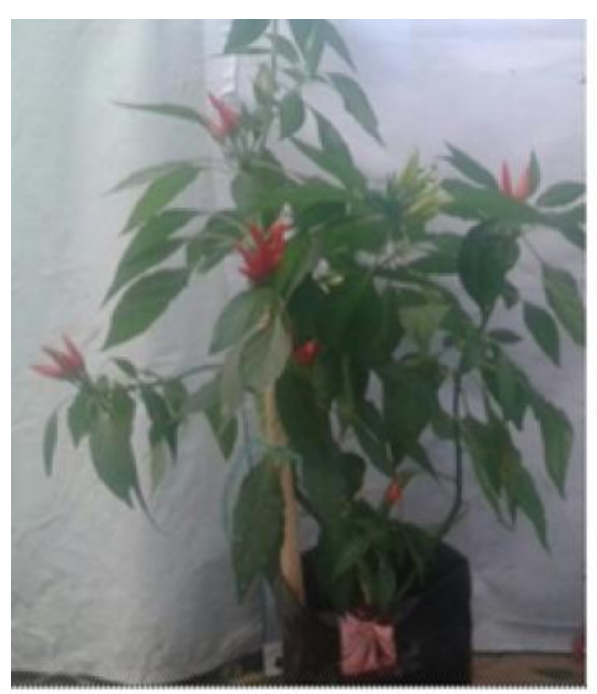

(a)

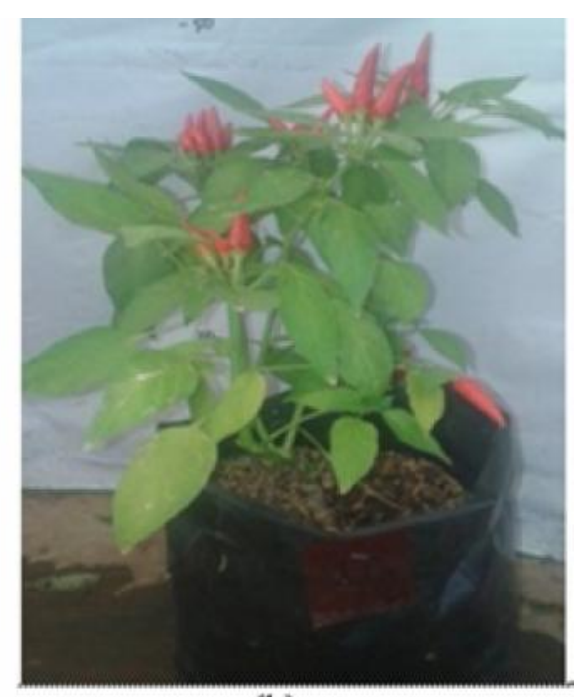

(b)

Gambar 1. (a). Cabai cv. "Candlelight" merah tanpa aplikasi paklobutrazol, (b) Cabai Candle light merah yang diharapkan

tanaman, jumlah buah, jumlah bunga, dan jumlah cabang (Tabel 1). Yasin (2009) Aplikasi paklobutrazol pada konsentrasi 0, 30, 60 dan 90 ppm meningkatkan jumlah tunas tanaman cabai tetapi konsentrasi $120 \mathrm{ppm}$ menurunkan jumlah tunas pada tanaman cabai. Penurunan jumlah tunas yang terbentuk disebabkan oleh penambahan paklobutrazol karena zat tersebut bersifat menurunkan aktivitas metabolisme jaringan.

Akibat terlalu cepatnya pemberian paklobutazol pada masa juvenil menyebabkan penyerapan paklobutrazol pada tanaman tidak efektif sehingga penurunan pada variabel jumlah daun total, jumlah buah, dan jumlah bunga. Penggunaan media sekam mentah yang tidak terdekomposisi secara sempurna menyebabkan pemupukan pada media campuran tidak efektif karena unsur hara yang diberikan ke media digunakan terlebih oleh mikroorganisme untuk mengdekomposisi sekam. Mikroorganisme membutuhkan nutrisi untuk kelangsungan hidupnya. Nutrisi tersebutlah yang berguna untuk memberikan energi dan membantu mikroba untuk melaksanakan aktivitasnya (Partaya, 2002). Hasil Penelitian media 
Tabel 2. Rekapitulasi hasil analisis ragam komposisi media tanam dan konsentrasi paklobutrazol terhadp keragaan tanaman cabai Candlelight

\begin{tabular}{|c|c|c|c|c|c|c|c|c|c|c|c|c|}
\hline \multirow{3}{*}{$\begin{array}{c}\text { Perbandinga } \\
n\end{array}$} & \multicolumn{12}{|c|}{ Variabel Pengamatan } \\
\hline & \multicolumn{3}{|c|}{ Vegetatif } & \multicolumn{9}{|c|}{ Generatif } \\
\hline & JD & TT & JT & MBP & JB & $\mathrm{JC}$ & $\mathrm{JBh}$ & $\mathrm{PC}$ & UB & $\begin{array}{c}\mathrm{PB} \\
\mathrm{h}\end{array}$ & $\mathrm{BBh}$ & $\begin{array}{l}\mathrm{K} \\
\mathrm{D}\end{array}$ \\
\hline \multicolumn{13}{|c|}{ Media Taman (M) } \\
\hline $\mathrm{P} 1: \mathrm{m}_{1} \mathrm{vs} \mathrm{m}_{2}$ & $*$ & $*$ & $*$ & $*$ & $*$ & $*$ & $*$ & $*$ & $*$ & $*$ & $*$ & $*$ \\
\hline \multicolumn{13}{|c|}{ Konsentrasi Paklobutrazol (D) } \\
\hline $\begin{array}{l}\text { P2: } \\
\text { konsentrasi } \\
\text { PBZ- linier }\end{array}$ & $*$ & $*$ & $*$ & $*$ & $*$ & $*$ & $*$ & $*$ & $*$ & $*$ & $*$ & $*$ \\
\hline $\begin{array}{l}\text { P3: } \\
\text { Konsentrasi } \\
\text { PBZ - } \\
\text { kuadratik }\end{array}$ & tn & $*$ & $*$ & * & tn & $\operatorname{tn}$ & $\operatorname{tn}$ & $*$ & * & $*$ & tn & $*$ \\
\hline \multicolumn{13}{|c|}{ Interaksi (M X D) } \\
\hline P4: P1 X P2 & $*$ & $*$ & $*$ & $*$ & $*$ & $*$ & $*$ & $\operatorname{tn}$ & $*$ & $*$ & tn & $*$ \\
\hline P5: P1 X P3 & tn & tn & tn & tn & tn & tn & tn & tn & * & tn & tn & $*$ \\
\hline \multicolumn{13}{|c|}{ Tanggapan Tanaman Cabai Terhadap Media Tanam } \\
\hline $\begin{array}{l}\mathrm{m}_{1}: \mathrm{PBZ}- \\
\text { linier }\end{array}$ & $*$ & $*$ & $*$ & $*$ & tn & $*$ & tn & - & tn & $*$ & - & $*$ \\
\hline $\begin{array}{l}\mathrm{m}_{1}: \mathrm{PBZ}- \\
\text { kuadratik }\end{array}$ & tn & tn & $*$ & tn & tn & tn & th & - & tn & $*$ & - & $*$ \\
\hline $\begin{array}{l}\mathrm{m}_{2}: \mathrm{PBZ}- \\
\text { linier }\end{array}$ & $*$ & $*$ & tn & $*$ & $*$ & $*$ & $*$ & - & $*$ & $*$ & - & $*$ \\
\hline $\begin{array}{l}\mathrm{m}_{2}: \mathrm{PBZ}- \\
\text { kuadratik }\end{array}$ & tn & $*$ & $*$ & tn & tn & tn & tn & - & $*$ & tn & - & $*$ \\
\hline
\end{tabular}

$\begin{aligned} & \text { Tanggapan Tanaman Cabai Terhadap Media Tanam dan Konsentrasi } \\
& \text { Paklobutrazol }\end{aligned}$
\begin{tabular}{lllllllllllll}
$\mathrm{d}_{0}: \mathrm{m}_{1} \mathrm{vs} \mathrm{m}_{2}$ & $*$ & tn & tn & tn & tn & tn & tn & - & tn & $*$ & - & tn \\
\hline $\mathrm{d}_{1}: \mathrm{m}_{1} \mathrm{vs} \mathrm{m}_{2}$ & $*$ & $*$ & tn & tn & tn & tn & tn & - & tn & $*$ & - & tn \\
\hline $\mathrm{d}_{2}: \mathrm{m}_{1} \mathrm{vs} \mathrm{m}_{2}$ & $*$ & $*$ & $*$ & $*$ & $*$ & $*$ & $*$ & - & tn & $*$ & - & $*$ \\
\hline $\mathrm{d}_{3}: \mathrm{m}_{1} \mathrm{vs} \mathrm{m}_{2}$ & $*$ & $*$ & $*$ & $*$ & $*$ & $*$ & $*$ & - & $*$ & $*$ & - & $*$ \\
\hline $\mathrm{d}_{4}: \mathrm{m}_{1} \mathrm{vs} \mathrm{m}_{2}$ & $*$ & $*$ & $*$ & $*$ & $*$ & $*$ & $*$ & - & $*$ & $*$ & - & $*$ \\
\hline
\end{tabular}

Keterangan: *: nyata pada taraf 5\%, tn: tidak nyata pada taraf 5\%, JD: jumlah daun total, TT: tinggi tanaman, JT: jumlah tunas, MBP: muncul bunga pertama, JB: jumlah bunga, JC: jumlah cabang, JBh: jumlah buah, PC: Panjang cabang, UB: Umur buah di pohon, PBh: Banjang buah, BBh: Bobot buah, KD: kehijauan daun.

tanam dan konsentrasi paklobutrazol dapat direkomendasikan karena media tanam $\mathrm{m}_{1}$ (sekam bakar) menghasilkan pengaruh yang lebih baik dibandingkan $\mathrm{m}_{2}$ (sekam bakar $50 \%+$ sekam mentah $50 \%$ ). Pengaruh media tanam $\mathrm{m}_{1}$ terlihat pada variabel tinggi tanaman, jumlah daun, dan jumlah buah. Media tanam $\mathrm{m}_{1}$ menghasilkan selisih $14,2 \mathrm{~cm}$ lebih tinggi dibandingkan $\mathrm{m}_{2}$. Media tanam $\mathrm{m}_{1}$ menghasilkan selisih 43 helai daun lebih banyak dibandingkan $\mathrm{m}_{2}$. Media tanam $m_{1}$ menghasilkan selisih 43 helai daun lebih banyak dibandingkan $\mathrm{m}_{2}$. Pengaruh konsentrasi paklobutrazol terlihat pada variabel tinggi tanaman dan jumlah daun total. Namun paklobutrazol konsentrasi $50 \mathrm{ppm}$ memberikan pengaruh nyata terhadap jumlah daun total, tinggi tanaman, jumlah tunas, muncul bunga pertama, jumlah bunga, jumlah cabang, jumlah buah, umur buah di pohon, panjang buah, dan kehijauan daun (Tabel. 1). Pada media sekam bakar setiap penambahan konsentrasi $1 \mathrm{ppm}$ paklobutrazol menurunkan tinggi tanaman sebesar $0,20 \mathrm{~cm}$, sedangkan pada media sekam campuran menurunkan tinggi tanaman sebesar $0,36 \mathrm{~cm}$ (Gambar 1.). Pada media sekam bakar setiap 


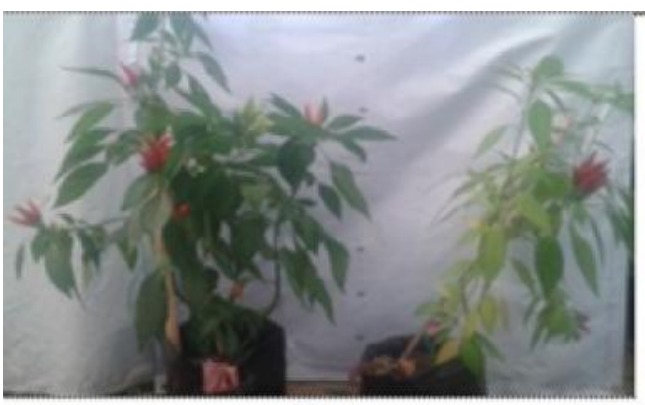

(a)

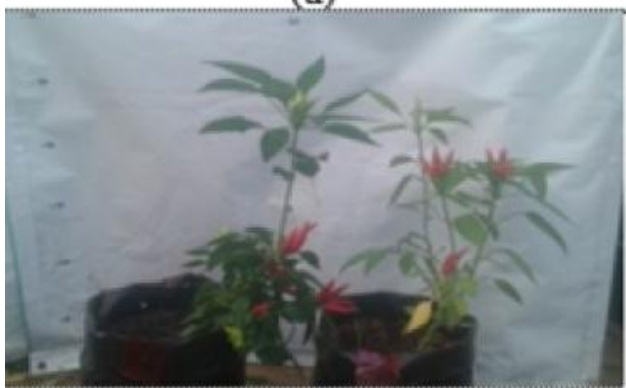

(c)

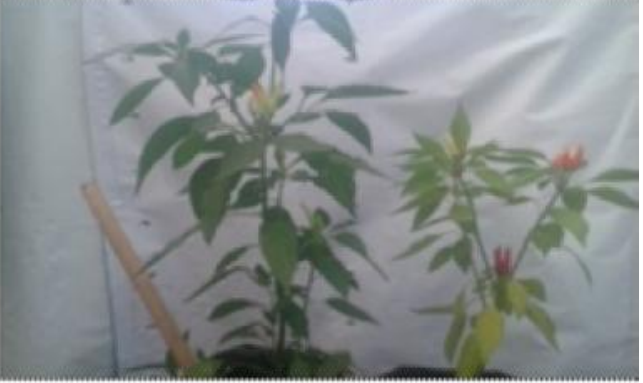

(b)

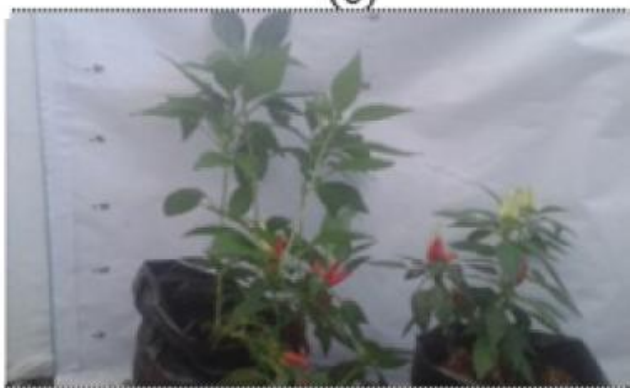

(d)

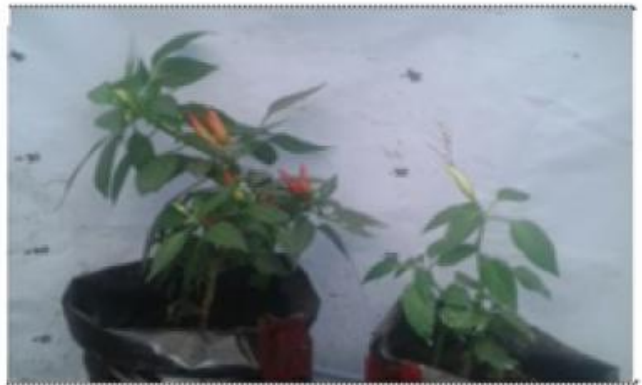

(e)

Gambar 2. Penampilan tanaman cabai CV. Candlelight pada tiap media tanam pada 0 ppm (a), 25 ppm (b), 50 ppm (c), 75 ppm (d), dan 100 ppm (e)

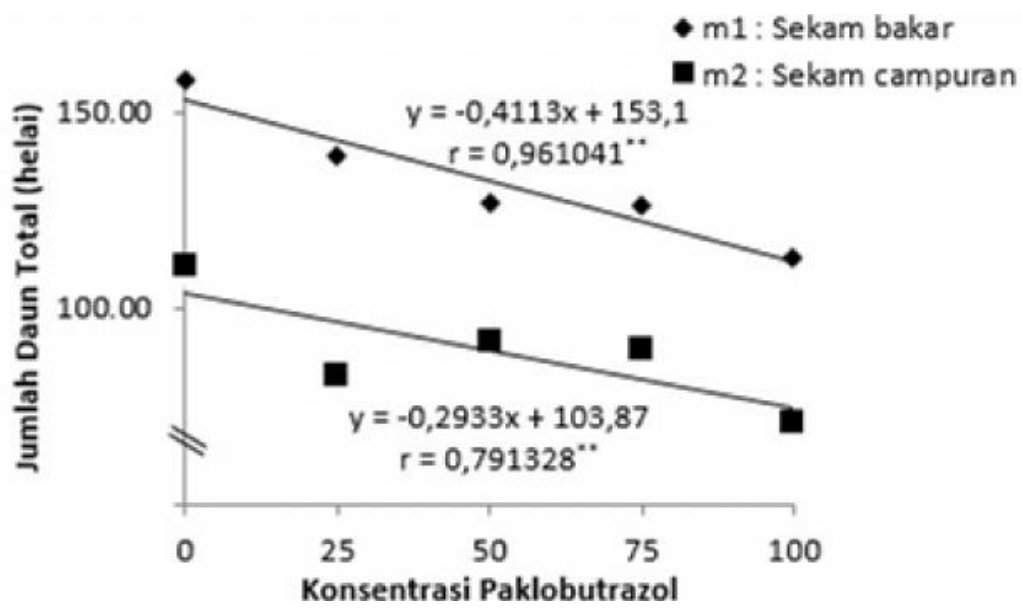

Gambar 3. Pengaruh konsentrasi paklobutrazol terhadap jumlah daun total $\mathrm{p}$ ada masing-masing media tanam 


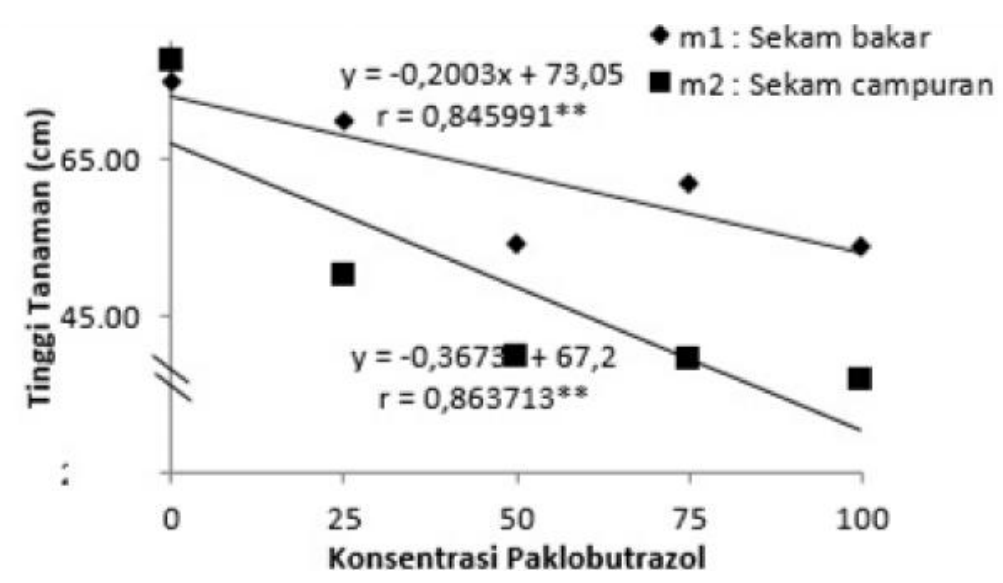

Gambar 4. Pengaruh konsentrasi paklobutrazol terhadap tinggi tanaman pada masing-masing media tanam

Tabel 3. Jumlah daun total, tinggi tanaman, jumlah tunas, muncul bunga pertama, jumlah bunga, jumlah cabang, jumlah buah, panjang cabang, umur buah di pohon, panjang buah, bobot buah, dan kehijauan daun tanaman cabai cv. "Candlelight" pada konsentrasi 50 ppm

\begin{tabular}{crrr}
\hline \multirow{2}{*}{ Variabel Pengamatan } & \multicolumn{2}{c}{ Konsentrasi Paklobutrazol 50 ppm } & \multirow{2}{*}{ Selisih } \\
\cline { 2 - 3 } & $\mathrm{m}_{1}$ & $\mathrm{~m}_{2}$ & 35,33 \\
Jumlah daun total & 126,83 & 91,50 & 14,33 \\
Tinggi tanaman & 54,33 & 40,00 & 3,67 \\
Jumlah tunas & 17,33 & 13,67 & 0,50 \\
Muncul bunga pertama & 2,00 & 1,50 & 18,00 \\
Jumlah bunga & 31,17 & 23,27 & 3,83 \\
Jumlah cabang & 8,50 & 4,67 & 16,33 \\
Jumlah buah & 27,50 & 11,17 & 4,31 \\
Panjang cabang & 8,58 & 4,27 & 0,17 \\
Umur buah di tanaman & 10,67 & 10,50 & 0,81 \\
Panjang buah & 3,19 & 2,38 & 39,61 \\
Bobot buah & 66,58 & 26,97 & 11,10 \\
Kehijauan daun & 76,30 & 65,20 &
\end{tabular}

penambahan konsentrasi 1 ppm paklobutrazol menurunkan jumlah daun total sebesar 0,40 helai, sedangkan pada media sekam campuran paklobutrazol menurunkan jumlah daun total sebesar 0,38 helai (Gambar 4). Jumlah buah pada media tanam sekam bakar tidak dipengaruhi oleh paklobutrazol tetapi pada media campuran pengaruh konsentrasi paklobutrazol memberikan pegaruh nyata.

\section{KESIMPULAN}

Berdasarkan hasil penelitian dapat disimpulkan bahwa: (1) Media sekam bakar menghasilkan keragaan tanaman cabai Candlelight lebih baik dibandingkan media campuran $(50 \%$ sekam bakar $+50 \%$ sekam mentah) pada semua variabel pengamatan. (2) Konsentrasi paklobutrazol 50 ppm menurunkan jumlah daun total, tinggi tanaman, jumlah bunga, jumlah cabang, jumlah buah, dan panjang buah serta meningkatkan jumlah tunas, muncul bunga pertama, umur buah di tanaman, dan kehijauan daun. (3) Pada media sekam bakar setiap penambahan konsentrasi 1 ppm paklobutrazol menurunkan tinggi tanaman sebesar 0,20 $\mathrm{cm}$, sedangkan pada media sekam campuran penambahan konsentrasi $1 \mathrm{ppm}$ paklobutrazol menurunkan tinggi tanaman sebesar $0,36 \mathrm{~cm}$.

\section{DAFTAR PUSTAKA}

Chaney, E. R. 2004. Paclobutrazol: More Than Just a Growth Retardant. Pro-Hort Conference, February 4th. Department of Forestry and Natural Resources. Purdue University, Peoria, Illinois. 
Marlina N, dan Rusnandi D. 2007. Teknik aklimatisasi bibit anthurium pada beberapa media tanam. Bul. Tek. pertanian. 12 (1): 38-40.

Partaya. 2002. Komunitas fauna tanah dan analisis bahan organik di TPA kota Semarang. Seminar Nasional: Pengembangan Biologi Menjawab Tantangan Kemajuan IPTEK, tanggal 29 April 2002. Semarang: Universitas Negeri Semarang.

Prihmantoro, H. dan Indriani, Y. H. 2003. Meтupuk Tanaman Sayur. Penebar Swadaya. Jakarta. 117 hlm.

Riyanti, Y. 2009. Pengaruh Jenis Media Tanam Terhadap Pertumbuhan Bibit Sirih Merah (Piper crocatum Ruiz and Pav.). Skripsi. Institut Pertanian Bogor. Bogor. 52 hlm.

Siswadi dan Yuwono T. 2015. Pengaruh Macam Media Terhadap Pertumbuhan Dan Hasil Selada (Lactuca sativa L) Hidroponik. Jurnal Agronomika 09 (03): 290-296.

Tumanggor P. T. 2006. Potensi Sisa Media Jamur Kuping sebagai Pupuk Organik pada Tanaman Tapak Dara (Chataranthus roseus (L.). Skripsi. Fakultas Pertanian Universitas Muhammadiyah Jakarta. Jakarta. 67 hlm.
Tonny K. M. dan Prabaningrum L. 2011. Program Komputer Meramu Pupuk Hidroponik AB Mix untuk Tanaman Parika. Puslitbang Holtikultura. $34 \mathrm{hlm}$

Wattimena, G. A. 1988. Zat Pengatur Tumbuh Tanaman. Lab. Jaringan Tanaman Bioteknologi IPB. Bogor. 145 hlm.

Wuryaningsih, S. 1996. Pertumbuhan Beberapa Setek Melati pada Tiga Macam Media. Jurnal Penelitian Pertanian. 5 (3): 50-57.

Yasin, Y.Y. 2009. Penggunaan Pupuk Daun dan Retardan Paklobutrazol terhadap Pertumbuhan dan Hasil Tanaman Cabai (Capsicum annuum) dalam Polybag. Skripsi. Program Studi Agronomi dan Hortikultura. Fakultas Pertanian. Institut Pertanian Bogor. Bogor. 69 hlm 